Володимир Оліферук, Національний університет оборони України імені Івана Черняховського ORCID ID 0000-0002-0722-7561 DOI: $10.33099 / 2617-1775 / 2020-01 / 210-221$

\title{
ЯКІСТЬ ОСВІТИ: ЕВОЛЮЦІЯ У ЯВЛЕНЬ У НАЦІОНАЛЬНОМУ ТА СВІТОВОМУ ОСВІТНЬОМУ ПРОСТОРІ
}

У статті розглядається підходи до визначення поняття “якість” з точки зору філософії, економіки, управління. Окреслено сутність поняття “якість освіти”, визначено низку факторів, які впливають на якість освіти. Аналізується інтегральна характеристика системи освіти, щзо відображає ступінь відповідності ресурсного забезпечення, освітнього процесу, освітніх результатів нормативним вимогам, соціальним ци особистісним очікуванням, а оцінка якості освіти - визначення за допомогою діагностичних та оціночних прочедур ступеня відповідності ресурсного забезпечення, організації освітнього процесу, освітніх результатів нормативним вимогам, соціальним й особистісним очікуванням.

Ключові слова: заклади вищої освіти; компетентність; прочеси навчання; якість освіти.

Забезпечення якості освіти є однією 3 головних умов, мобільності, сумісності та привабливості системи вищої освіти будь-якої країни, головною складовою престижу закладу вищої освіти (ЗВО). Сприяння європейському співробітництву в забезпеченні якості освіти - це вимога Болонського процесу, а принцип інституційної автономії передбачає, що основна відповідальність за забезпечення якості лежить на ЗВО. У світовій практиці застосовуються різні підходи в оцінюванні якості роботи 3ВО: експертний (на основі експертних оцінок), результативний (за об’єктивними показниками) та загальний.

Завдання забезпечення якості вищої освіти є багатоплановим і включає наявність необхідних ресурсів (кадрових, фінансових, матеріальних, інформаційних, наукових, навчально-методичних тощо), організацію навчального процесу, яка найбільш адекватно відповідає сучасним тенденціям розвитку національної та світової економіки та освіти, контроль освітньої діяльності 3ВО та якості підготовки фахівців на всіх етапах підготовки та на всіх рівнях (рівні 3ВО, державному рівні, міжнародному (європейському) рівні).

Поняття “якість" визначається 3 різних точок зору - філософської, соціальної, політичної, економічної, педагогічної, демографічної та інших, але зміст цього поняття й надалі продовжує доповнюватися та конкретизуватися. На сьогодні можна виділити основні тлумачення поняття “якість" як відповідність призначенню, оцінка, показник продукту чи послуги, відповідність вартості, відповідність стандартам та ступінь задоволення потреб споживачів.

Міжнародною організацією зі стандартизації (ISO) “якість” визначається як ступінь, відповідно до якого, сукупність власних характеристик задовольняє вимогам і розглядається не тільки як результат діяльності, але й як можливості 
його досягнення у вигляді внутрішнього потенціалу та зовнішніх умов, а також як процес формування характеристик [2].

Аналіз документів, що стосуються процесу забезпечення та гарантування якості вищої освіти у деяких країнах-членах НАТО та Україні виявив наявність термінологічної багатоманітності щодо визначення поняття “якість освіти” у різних площинах - концептуальній, теоретичній і методологічній (табл. 1). Категорія “якість освіти” в нормативних документах різних країн розглядається 3 позицій зацікавлених сторін (stakeholders) освітнього процесу: держави, суспільства, закладу освіти, роботодавців, студентів тощо [3].

Існують різні підходи щодо визначення поняття "якість освіти". За міжнародними освітніми програмами якість освіти розглядається як ступінь відповідності реальних результатів освіти ринковій кон'юнктурі, показнику матеріально-технічної і ресурсної забезпеченості освітнього процесу, комплексному показнику чинників престижності та економічної ефективності освіти, показнику досконалості змісту, технологій і системи оцінки досягнень, показнику інвестиційної принадності освіти тощо [4].

Визначення понять "якість освіти"

Таблиця 1

\begin{tabular}{|c|c|}
\hline Країна & Визначення ключових понять \\
\hline Бельгія & $\begin{array}{l}\text { Якість освіти трактується з точки зору виконання вимог, потреб чи } \\
\text { бажань замовника послуг. } \\
\text { Якість у вищій освіті (quality in higher education) - це складний і } \\
\text { багатогранний термін. Інтерпретація поняття відрізняється в } \\
\text { залежності від цільової групи та рівня освіти; змінюєтья в часі; } \\
\text { визначається передумовами, в яких якість можна опрацювати в } \\
\text { контексті освіти. Така багатогранність інтерпретації терміну } \\
\text { перетворює оцінку якості на складний процес, в якому має бути } \\
\text { приділена належна увага очікуванням великої кількості учасників } \\
\text { (заклад вищої освіти, студенти та їні батьки, працедавці, торговельні } \\
\text { організації, суспільство в цілому та уряд) }\end{array}$ \\
\hline Болгарія & $\begin{array}{l}\text { Якість (quality) - сукупність властивостей і характеристик, які } \\
\text { відрізняють один об’єкт, явище чи процес від аналогічних йому щодо } \\
\text { міри ефективності. Природа якості може бути описана у різній } \\
\text { термінології: } \\
\text { гарантування якості (quality guarantee); } \\
\text { оцінка якості (quality evaluation); } \\
\text { підтримка якості (quality maintenance); } \\
\text { управління якістю (quality management); } \\
\text { забезпечення якості (quality assurance) }\end{array}$ \\
\hline Італія & $\begin{array}{l}\text { Якість стимулюється і оцінюється через оцінку результатів у } \\
\text { різних галузях - науковій, освітній, виховній та по відношенню до } \\
\text { наявних ресурсів та структур }\end{array}$ \\
\hline Німеччина & $\begin{array}{l}\text { Якість (quality) - вагомість/обгрунтованість і досягнення цілей; } \\
\text { елементи якості (планування, управління, стимулювання та результати) } \\
\text { визначаються як вимоги для кожної освітньої програми (програми } \\
\text { акредитації) }\end{array}$ \\
\hline
\end{tabular}




\begin{tabular}{|c|c|}
\hline Польща & $\begin{array}{l}\text { Якість розглядається через виконання стандартів навчання - } \\
\text { сукупність норм, які визначають зміст вищої освіти при здійсненні } \\
\text { підготовки викладацьких кадрів, а також кадрів, для яких вимоги щодо } \\
\text { процесу навчання та його результатів визначені у нормах права } \\
\text { Європейського Союзу }\end{array}$ \\
\hline $\begin{array}{c}\text { Сполучене } \\
\text { Королівство }\end{array}$ & $\begin{array}{l}\text { Академічна якість (academic quality) - це спосіб опису того, } \\
\text { наскільки ефективно наявні освітні можливості допомагають у } \\
\text { досягненні певного ступеня освіти, наскільки відповідними і } \\
\text { ефективними є викладання, матеріальна забезпеченість, оцінювання та } \\
\text { можливості для навчання }\end{array}$ \\
\hline Хорватія & $\begin{array}{l}\text { Якість у науці та вищій освіті (quality in science and higher } \\
\text { education) - багатовимірне i динамічне поняття } 3 \text { акцентом на } \\
\text { задоволення загальноприйнятих стандартів і очікувань суспільства в } \\
\text { цілому, бажання постійно покращувати всі процеси та їх результати }\end{array}$ \\
\hline ВiTЧL & яному освітньому просторі “якість освіти” здебільшо \\
\hline
\end{tabular}
визначають [5]:

- ступенем відповідності цілей і результатів освіти на рівні конкретної системи освіти й на рівні окремої освітньої установи;

- відповідністю між різними параметрами в оцінці результату освіти конкретної людини (якістю знань, ступенем сформованості відповідних умінь i навичок, розвиненістю відповідних творчих та індивідуальних здібностей, властивостей особистості й ціннісних орієнтацій);

- ступенем відповідності теоретичних знань і вмінь їхньому практичному використанню в житті й професійній діяльності, у розвитку потреби людини в постійному відновленні своїх знань i вмінь та беззупинному їх вдосконалюванні.

Деякі автори під “якістю освіти” розуміють сукупність основних компетентностей, прав та обов'язків, які висуваються до різних спеціальностей (табл. 2).

Таблиця 2

Визначення поняття "якість освіти"

\begin{tabular}{|c|c|c|}
\hline Автор & Визначення поняття & Джерело \\
\hline Рибальченко Д. & $\begin{array}{l}\text { Збалансована відповідність освіти (як результату, } \\
\text { процесу, освітньої системи) установленим потребам, } \\
\text { цілям, вимогам, нормам (стандартам) }\end{array}$ & [6] \\
\hline Коротков $\mathrm{C}$. & $\begin{array}{l}\text { Комплекс характеристик компетентностей } \\
\text { професійної свідомості, що відбивають здатність фахівця } \\
\text { здійснювати професійну діяльність відповідно до вимог } \\
\text { сучасного етапу розвитку економіки }\end{array}$ & [7] \\
\hline Поберезька Г. & $\begin{array}{l}\text { Сукупність властивостей та характеристик освітнього } \\
\text { процесу, що надають йому спроможністьиформувати } \\
\text { рівень професійної компетентності, який задовольняє } \\
\text { потреби громадян, підприємств і організацій, суспільства і } \\
\text { держави }\end{array}$ & [8] \\
\hline Головань М. & $\begin{array}{l}\text { Сукупність властивостей і характеристик освітнього } \\
\text { процесу, що надають йому здатність задовольняти } \\
\text { зумовлені потреби в знаннях і навичках окремих громадян, } \\
\text { підприємств і організацій, суспільства і держави }\end{array}$ & [9] \\
\hline Панасюк В. & Сдність якості процесу (діяльності) і якості результату & {$[10]$} \\
\hline
\end{tabular}




\begin{tabular}{|l|l|c|c|}
\hline Кравченко Ю. & $\begin{array}{l}\text { Модель соціальних норм і вимог до особистості, } \\
\text { освітнього середовища, в якому відбувається їі розвиток, } \\
\text { та системи освіти, що реалізує ці норми і вимоги на певних } \\
\text { етапах навчання людини }\end{array}$ & \\
\hline Міжериков В. & $\begin{array}{l}\text { Стан і результативність процесу освіти в суспільстві, } \\
\text { його відповідність потребам і очікуванням суспільства у } \\
\text { розвитку та формуванні громадянських, цивільних, }\end{array}$ & \\
& побутових і професійних компетенцій & \\
\hline Моїсеєв А. & $\begin{array}{l}\text { Сукупність властивостей і характеристик результатів } \\
\text { освіти, здатних задовольнити потреби суспільства, } \\
\text { замовників освіти. }\end{array}$ & {$[13]$} \\
\hline Шишов С. & Ступінь задоволення очікувань різних учасників & [14] \\
& $\begin{array}{l}\text { процесу освіти від наданих освітнім закладом освітніх } \\
\text { послуг }\end{array}$ & \\
\hline
\end{tabular}

Вчені В. Воротілов та Г. Шапоренкова [15] виділяють тринадцять підходів до визначення якості освіти:

- інтуїтивно-емпіричний (досвід та інтуїція людини);

- формально-підзвітний (рівень успішності тих, хто навчається);

- психологічний (рівень вихованості та навченості);

- процесуальний (оцінка стану навчального процесу);

— результуючий (оцінка результату педагогічної діяльності освітнього закладу);

- комплексний (зовнішня експертиза матеріальної бази, кадрового складу, програм, форм і методів роботи тощо);

- багатопараметричний (оцінка діяльності закладу на основі внутрішньосистемних параметрів);

- методологічний (співвідношення результату із заданими цілями);

- інтегрований (введення категорій, що носять інтегрований характер, компетентність, грамотність, освіченість);

- особистісно-орієнтований (розвиток особи того, хто навчається);

- соціальний (ступінь задоволення індивідуального і суспільного споживача);

- кваліметричний (вимірювання показників за параметрами).

Р. Кучма визначає якість вищої освіти як збалансовану відповідність освіти (результату, процесу, освітньої системи) визначеним потребам, цілям, вимогам, нормам (стандартам), що відповідають необхідності сучасного суспільного розвитку. Автор вважає, що якість вищої освіти складається з якості таких компонентів, як якість викладання (навчального процесу, педагогічної діяльності), якість науково-педагогічних кадрів, якість освітніх програм, якість матеріально-технічної бази та інформаційно-освітнього середовища, якість абітурієнтів, якість наукових досліджень, якість управління освітою [16].

Аналіз визначень показує варіативність підходів до розуміння поняття “якість освіти", що надає можливості виокремити трактування якості освіти через іiі сутність та відповідність нормам якості освіти, визнаній системі освіти, вимогам стандартів, очікуванням суспільства і держави, розвитку економіки (рис. 1). 


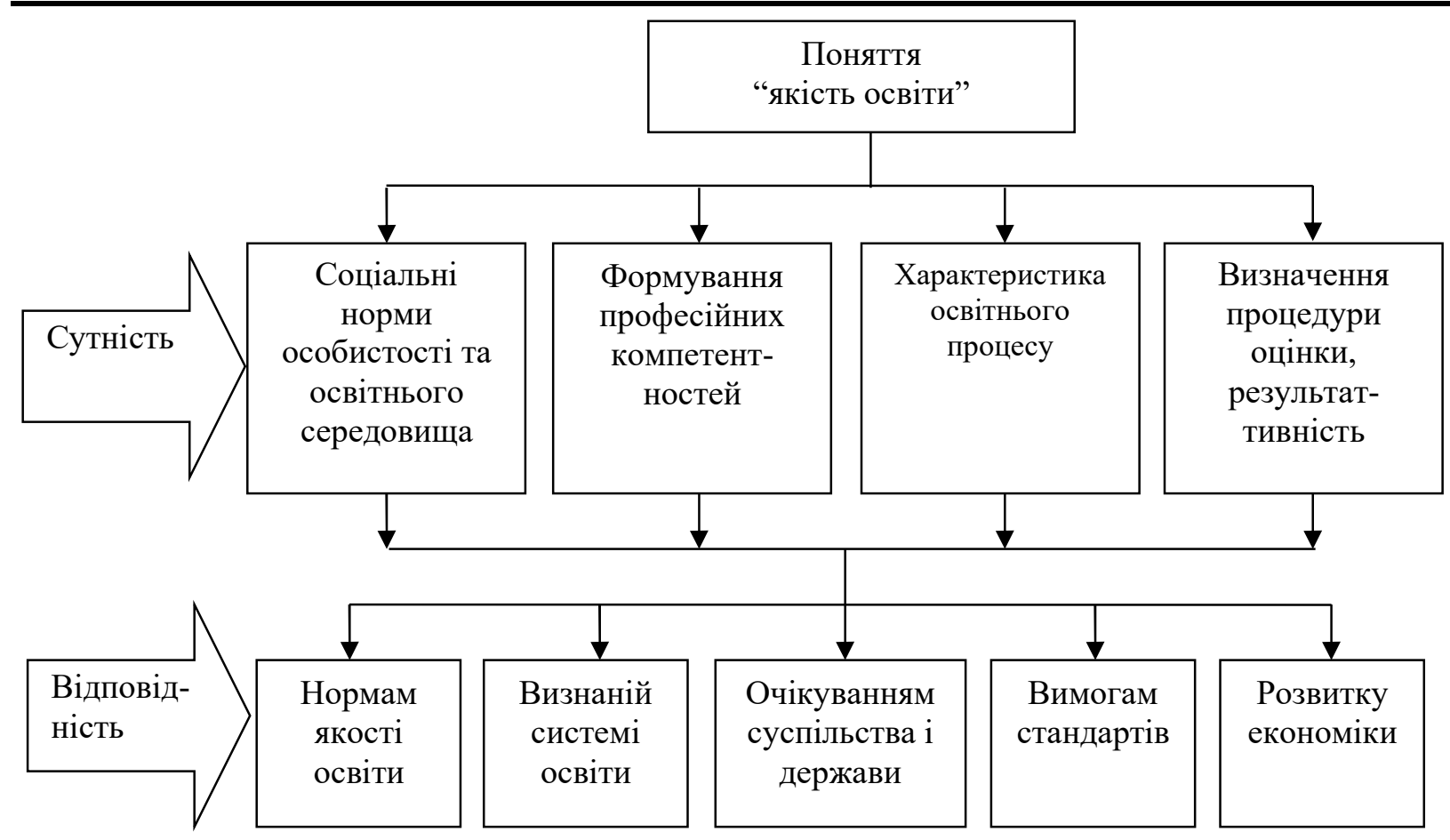

Рис. 1. Визначення поняття “якість освіти”

Для реалізації інтеграційних процесів навчання якість освіти забезпечується вимогам міжнародних стандартів, закладами вищої освіти та гарантуватися державою. Тому, у Законі України "Про освіту" “якість освіти" визначається як “відповідність результатів навчання вимогам, встановленим законодавством, відповідним стандартом освіти та/або договором про надання освітніх послуг" [17].

Стосовно вищої освіти поняття “якість” має різні значення у залежності:

від вимог сторін, які зацікавлені в діяльності 3ВО, а саме держави, замовника, тих, хто навчається, науково-педагогічного складу;

від якості тієї академічної галузі, яку треба оцінити;

від історичного періоду в розвитку вищої освіти тощо.

Тому не випадково, що поняття “якість вищої освіти" має різноманітні інтерпретації. У Меморандумі про вищу освіту Комісії Свропейських співтовариств, що був надрукований у 1991 році, якість визначається як найбільш ефективне використання людських i матеріальних ресурсів вищої школи, поширення наукових досліджень i максимально можливе їх застосування в навчальному процесі, удосконалення i оптимізація вступу до ЗВО i форм атестації студентів, покращення професійної компетенції викладачів, поглиблення взаємодії з роботодавцями.

У Всесвітній декларації про вищу освіту для XXI століття, що була прийнята у 1998 році на організованій ЮНЕСКО Всесвітній конференції 3 вищої освіти, якість у галузі вищої освіти трактується як багатовимірна концепція, яка охоплює всі іiі функції, види діяльності та ресурси: навчальні i академічні програми; наукові розробки і стипендії; комплектацію кадрами; будівельні споруди; матеріально-технічну базу; устаткування; роботу на благо суспільства і академічне середовище” [1]. Крім того, у документах ЮНЕСКО 
якість вищої освіти є поняттям, яке характеризується численними аспектами i значною мірою залежить від контекстуальних рамок цієї системи, інституціональних завдань чи умов і норм у певній дисципліні [18], [19].

У закордонній науковій літературі останнім часом спостерігається тенденція до побудови багатовимірних моделей якості вищої освіти, де різним вимірам відповідають різні підходи до цього поняття. Зокрема, популярною $є$ загальна модель Л. Харвій і Д. Гріна, згідно з якою вирізняють такі аспекти поняття якості вищої освіти [20], як:

виключність (прагнення бути кращим за інших);

досконалість або стабільність;

придатність до певних цілей (відповідність вимогам клієнтів, потребам або бажанням);

співвідношення 3 ціною (можливість та термін повернення інвестицій у вищу освіту).

Близькою до їх підходу є модель Ж. Перрі, який додатково виокремлює якість вищої освіти як атрибут, що характеризує постійний розвиток [21]. Усе більшого поширення в управлінні якістю вищої освіти набуває модель досконалості Європейської організації менеджменту якості (EFQM (European Foundationfor Quality Management) Excellence Model) [22]. Вона базується на дев’яти показниках. П'ять із них (лідерство, управління персоналом, політика i стратегія, забезпечення ресурсами та ефективність їх використання, технологічні процеси) характеризують якість вищої освіти як можливості, що відображають діяльність установи, а інші чотири (задоволення співробітників, споживачів, вплив на зовнішне середовище, реалізація потенційних можливостей) - результати, зумовлені можливостями, та зворотний зв'язок від досягнутих результатів, спрямований на покращення можливостей.

У межах проекту UNESCO-CEPES “Стратегічні показники вищої освіти в XXI столітті" відображені такі основні підходи до визначення якості вищої освіти [23]:

якість вищої освіти як зверхність (високий рівень складності програми, процедур тестування студентів, імідж ЗВО не тільки на національному, але й на міжнародному рівні);

якість як відповідність поставленим цілям (відповідність загальноприйнятим стандартам, визначеним акредитаційним органом, 3 акцентом на досягнуті результати освітнього процесу або навчальної програми);

якість як задоволення споживача (виправдання очікувань споживачів студентів, батьків, суспільства в цілому та інших зацікавлених сторін);

якість як синонім покращення (процес, спрямований на постійне вдосконалення, розвиток відповідальності ЗВО за краще використання його інституційної автономії та свободи).

У сучасному "Національному освітньому глосарії: вища освіта" якість вищої освіти визначена як рівень здобутих особисто, що відображають іiі компетентність відповідно до стандартів вищої освіти, а якість освітньої діяльності як рівень організації освітнього процесу у ЗВО, що відповідає 
стандартам вищої освіти, забезпечує здобуття особами якісної вищої освіти та сприяє набуття нових знань [24].

У Законі України "Про вищу освіту" “якість вищої освіти” визначається як рівень здобутих особою компетентностей відповідно до стандартів вищої освіти [25].

Кожний із наведених підходів до визначення поняття "якість вищої освіти" має свої переваги й обмеження в залежності від певного етапу розвитку вищої освіти, національної специфіки сприйняття, вимог, що висуваються ринком праці. У той же час елементами, що інтегрують різноманітні підходи до визначення якості в системі вищої освіти, є:

гарантоване виконання вимог освітніх стандартів i реалізація процесу бенчмаркінгу;

спроможність ставити чіткі цілі у відповідності до вимог часу і досягати їх; спроможність відповідати вимогам споживачів та інших зацікавлених сторін;

постійний рух до підвищення якості освіти.

На наш погляд, при визначенні поняття “якість вищої освіти” слід спиратися на три основні підходи, які знайшли відображення в сучасній соціально-філософській думці:

об’єктивістський - проводить аналіз якості вищої освіти на підставі вхідних параметрів освітньої системи ЗВО (професійного рівня викладачів, рівня матеріально-технічного забезпечення, рівня знань студентів на початковому етапі навчання тощо), i вихідних параметрів (рейтингу випускників, можливості працевлаштування тощо);

релятивістський підхід - спирається на досягнення цілей навчання. Виявляється, наскільки рівень навчальних досягнень студентів відповідає запланованому результату у вигляді вимог освітніх стандартів;

компетентнісний підхід - орієнтований на вдосконалення якості освітнього процесу в поточний період. При оцінюванні якості вищої освіти розглядають творчу пізнавальну активність студентів, рівень сформованих у них визначених компетенцій.

Сучасні українські дослідження свідчать, що основними чинниками, які забезпечують якість освіти, є [3]-[5], [8], [16]:

професійна підготовка суб'єктів викладання, їхні особистісні якості (порядність, відповідальність, принциповість, толерантність тощо);

навчально-методичне забезпечення процесу підготовки (навчальні посібники, методичні розробки);

наявність системи контролю й оцінювання викладання, рівня знань суб’єктів учіння, що відповідає сучасним вимогам;

застосування в освітньому процесі сучасних освітніх технологій (активних методів навчання, Інтернет-технологій тощо);

залучення суб'єктів освітнього процесу до науково-дослідницької діяльності;

відповідність програм навчальних дисциплін сучасним вимогам;

контакти з провідними іноземними фахівцями; 
належне матеріально-технічне забезпечення процесу підготовки;

забезпеченість науковою літературою освітніх закладів;

використання матеріалів психолого-соціологічних та інших досліджень;

спрямованість викладання на формування соціальних якостей сучасного фахівця;

стимулювання самостійної роботи суб'єктів навчання, тощо.

Виходячи 3 викладеного під якістю вищої освіти, у даному звіті, будемо розуміти комплекс характеристик освітнього процесу, що визначають послідовне і практично ефективне формування компетентності та професійної свідомості. Визначимо три групи характеристик - якість потенціалу досягнення мети освіти, якість процесу формування професіоналізму і якість результату освіти. Названі групи характеристик представлені на рис. 2.

Якість потенціалу виражається в таких характеристиках, як якість мети освіти, якість стандарту вищої освіти, якість освітньої програми, якість матеріально-технічної бази освітнього процесу, якість абітурієнтів, якість інформаційно-методичної бази.

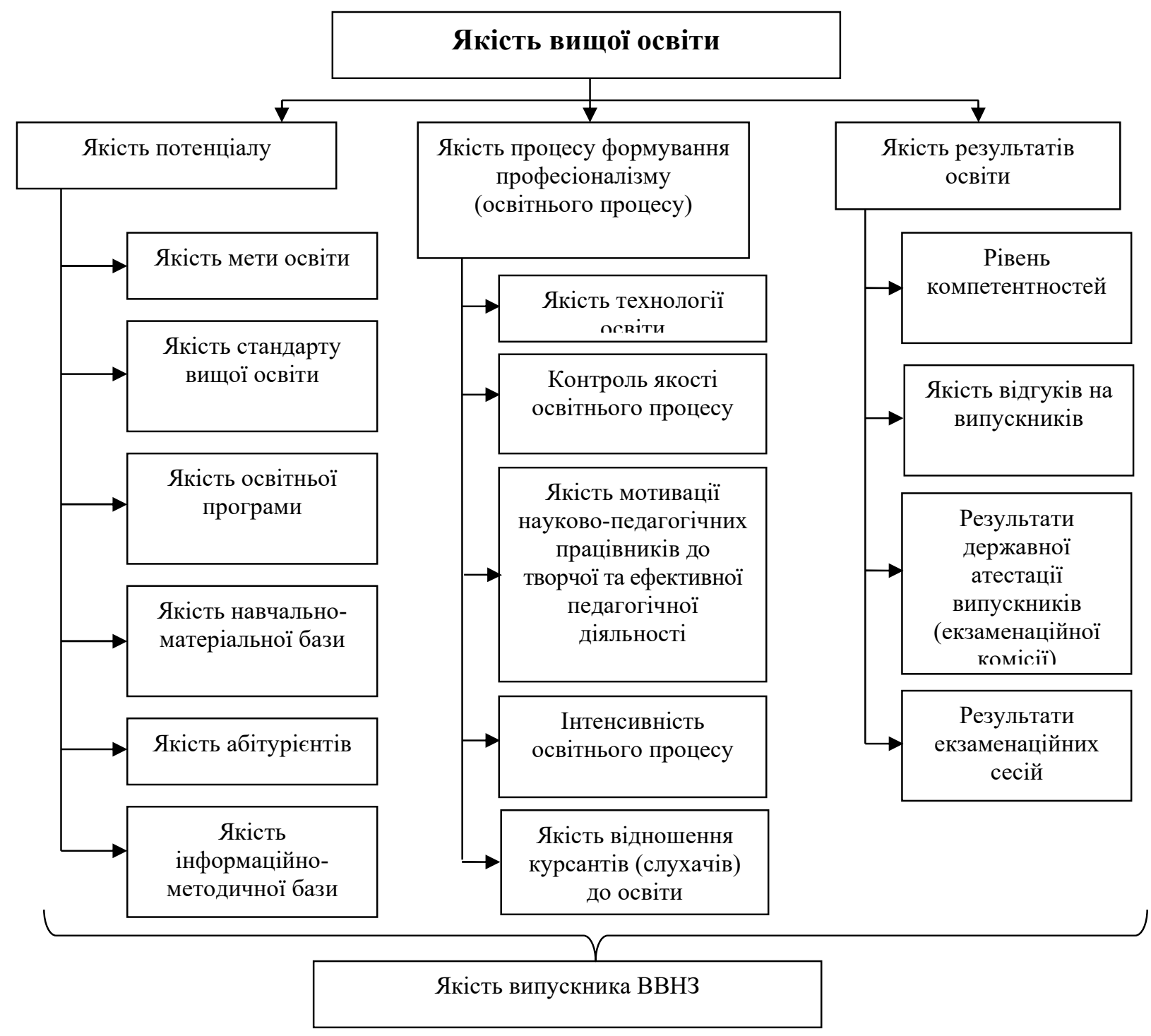

Рис. 2. Структура якості вищої освіти 
Якість процесу формування професіоналізму - це якість технології освіти, контроль якості освітнього процесу, якість мотивації науково-педагогічних працівників (НПП) до творчої та ефективної педагогічної діяльності, якість відношення курсантів (слухачів, студентів) до освіти, інтенсивність освітнього процесу.

Якість результатів освіти - рівень сформованості компетенцій, якість відгуків на випускників, результати державної атестації випускників (державної екзаменаційної комісіі) та результати екзаменаційних сесій.

Таким чином, центральною ланкою системи управління та забезпечення якості є освітній процес. Контроль у системі забезпечення якості підготовки фахівців має на меті виявлення найбільш слабких сторін навчального процесу шляхом самооцінки діяльності $3 \mathrm{BO}$, яка проводиться систематично за критеріями, визначеними стандартами вищої освіти, та відповідно до вимог центральних органів управління освітою. Іншими складовими системи $\epsilon$ проведення регулярних опитувань (анкетування) студентів, випускників та їх потенційних замовників; введення модульної системи організації навчального процесу тощо.

\section{ЛІТЕРАТУРА}

1. Вища освіта України і Болонський процес: навч. посіб. / М.Ф. Степко, Я. Я. Болюбаш, В. Д. Шинкарук， В.В.Грубінко, І.І.Бабин; Заред. В.Г.Кременя. - Т. : Навчальна книга - Богдан, 2004. - С. 171.

2. ДСТУ ISO 9000:2007. Системи управління якістю. Основні положення та словник. - К.: Держстандарт України, 2007. - 42 с.

3. Розвиток системи забезпечення якості вищої освіти в Україні: інформаційноаналітичний огляд / Укладачі: Т. Добко, І. Золотарьова, С. Калашнікова, В. Ковтунець, С. Курбатов， І. Линьова， В. Луговий， І. Прохор， Ю. Рашкевич， І. Сікорська， Ж. Таланова, Т. Фініков, С. Шаров; за заг. ред. С. Калашнікової та В. Лугового. - Київ: ДП "НВЦ “Пріоритети', 2015. - 84 с.

4. Байденко В. І. Про можливість побудови єдиного Макету освітнього стандарту країн СНД як динамічної моделі норми якості вищої освіти / [В. І. Байденко, В. Ф. Пугач, Н. М. Рогозіна та ін.] // Болонський процес в Україні: наук.-метод. зб. - 2005. - Вип. 46. - С. $40-61$.

5. Шабанова Ю. О. Системний підхід у вищій школі: підруч. для студ. магістратури/ Ю. О. Шабанова; М-во освіти і науки України; Нац. гірн. ун-т. - Д. : НГУ, 2014. $-120 \mathrm{c}$.

6. Рибальченко Д. О. Методологічні засади створення та впровадження системи управління якістю освітніх послуг / Д. О. Рибальченко [Електронний ресурс]. - Режим доступу: http://nvd.luguniv.edu.ua/archiv/NN15/11rdoznz.pdf.

7. Коротков С. Концепція якості освіти / Є. Коротков // Підручник для директора. 2006. - № 7. - C. 4-24.

8. Поберезька Г. Г. Тенденції розвитку вищої освіти країн Західної Європи та України : дис. канд. пед. наук : 13.00 .01 / Г. Г. Поберезська ; Ін-т вищ. освіти АПН України. К., 2005. $-217 \mathrm{c}$.

9. Головань М. Компетенція і компетентність: досвід теорії, теорія досвіду / М. Головань // Вища освіта України. - 2008. - № 3. - С. 23-30.

10. Панасюк В. Використання досвіду управління якості освіти / В. Панасюк // Підручник для директора. - 2007. - № 8. - С. 42-51. 
11. Кравченко Ю. Качество образования - фактор повышения качества жизни / Ю. Кравченко, О. Лебедев // Стандарты и качество. - 2007. - № 6. - С. 20-22.

12. Міжеріков В.А. Словник-довідник з педагогіки / Авт.-упоряд. В.А. Міжеріков; під заг. ред. П.І. Підкасистого. - С. 139-140.

13. Моїсеєв А. М. Управління школою: словник-довідник керівника освітньої установи / Під ред. А. М. Моїсеєва, А. А. Хлань. - М., 2005. - С. 101-102.

14. Шишов С. Е. Школа: мониторинг качества образования / С. Е. Шишов, В. А. Кальней. - К . : КНЕУ, 2004. - 167 с.

15. Воротилов В. Анализ основных подходов к определению качества образования / В. Воротилов, Г. Шапоренкова // Высшее образование в России. - 2006. - № 11. - С. 47-56.

16. Кучма Р. М. Сучасні системи управління якістю вищої освіти в контексті вимог Болонського процесу / Р. М. Кучма // Вісн. Київ. нац. ун-ту ім. Тараса Шевченка. Філософія. Політологія. - 2010. - Вип. 94-96. - С. 87-93.

17. Про освіту : Закон України від 5 вересня 2017 року № 2145-VIII із змінами. [Електронний ресурс]. - Режим доступу: https://zakon.rada.gov.ua/laws/show/2145-19.

18. Науково-освітній потенціал нації: погляд у XXI століття: програмний документ ЮНЕСКО /Авт. кол.: В. Литвин, В. Андрущенко, С. Довгий. - К. : Навч. книга, 2003. - С. $352-354$.

19. Определение качества в образовании / Джанетт Колбі, Міске Уїтт // Материалы ЮНИСЕФ: доклад 16 июля 2000 г. - Нью-Йорк, 2000. - 157 с.

20. Harvey L. Defining quality / L. Harvey, D. Green // Assessment and Evaluation in Higher Education. - 1993. - V. 18 (1). - P. 9-34.

21. Parri J. Quality in Higher Education / J. Parri // Management. - 2006. - № 2 (11) - P. $107-111$.

22. The EFQM Excellence Model. - [Електронний ресурс]. - Режим доступу: http://www.ddexcellence.com/About 20 Excellence/Model.git on 6 August 2009.

23. Гарантии качества высшего образования: Глоссарий // Экспертиза качества профессионального образования : материалы семинара, 20-22 июня 2014 г. - М. : МГУ им. М. П. Огарёва, 2014. - 315 с.

24. Національний освітній глосарій: вища освіта / [В. М. Захарченко, С. А. Калашнікова, В. І. Луговий та ін.] / За ред. В. Г. Кременя. - К. : ТОВ ВД “Плеяди", 2014. $-100 \mathrm{c}$.

25. Про вищу освіту : Закон України від 1 лип. 2014 р. № 1556-VII // Офіц. вісн. України. - 2014. - № 63. - Ст. 1728. - [Електронний ресурс]. - Режим доступу: http://zakon.rada.gov.ua.

\section{REFERENCES}

1. Vyshcha osvita Ukrainy i Bolonskyi protses : navch. posib. / M. F. Stepko, Ya. Ya. Boliubash, V. D. Shynkaruk, V. V. Hrubinko, I. I. Babyn; Za red. V. H. Kremenia. - T. : Navchalna knyha - Bohdan, 2004. - S. 171.

2. DSTU ISO 9000:2007. Systemy upravlinnia yakistiu. Osnovni polozhennia ta slovnyk. K.: Derzhstandart Ukrainy, 2007. - 42 s.

3. Rozvytok systemy zabezpechennia yakosti vyshchoi osvity v Ukraini: informatsiinoanalitychnyi ohliad / Ukladachi: T. Dobko, I. Zolotarova, S. Kalashnikova, V. Kovtunets, S. Kurbatov, I. Lynova, V. Luhovyi, I. Prokhor, Yu. Rashkevych, I. Sikorska, Zh. Talanova, T. Finikov, S. Sharov; za zah. red. S. Kalashnikovoi ta V. Luhovoho. - Kyiv: DP "NVTs "Priorytety, 2015. -84 s.

4. Baidenko V. I. Pro mozhlyvist pobudovy yedynoho Maketu osvitnoho standartu krain CND yak dynamichnoi modeli normy yakosti vyshchoi osvity / [V. I. Baidenko, V. F. Puhach, N. M. Rohozina ta in.] // Bolonskyi protses v Ukraini: nauk.-metod. zb. - 2005. - Vyp. 46. - S. 40-61.

5. Shabanova Yu. O. Systemnyi pidkhid u vyshchii shkoli: pidruch. dlia stud. mahistratury/ Yu. O. Shabanova; M-vo osvity i nauky Ukrainy; Nats. hirn. un-t. - D. : NHU, 2014. - 120 s. 
6. Rybalchenko D. O. Metodolohichni zasady stvorennia ta vprovadzhennia systemy upravlinnia yakistiu osvitnikh posluh / D. O. Rybalchenko [Elektronnyi resurs]. - Rezhym dostupu: http://nvd.luguniv.edu.ua/archiv/NN15/1 1rdoznz.pdf.

7. Korotkov Ye. Kontseptsiia yakosti osvity / Ye. Korotkov // Pidruchnyk dlia dyrektora. 2006. - № 7. - S. 4-24.

8. Poberezka H. H. Tendentsii rozvytku vyshchoi osvity krain Zakhidnoi Yevropy ta Ukrainy : dys. kand. ped. nauk : 13.00.01 / H. H. Poberezska ; In-t vyshch. osvity APN Ukrainy. K., 2005. $-217 \mathrm{~s}$.

9. Holovan M. Kompetentsiia i kompetentnist: dosvid teorii, teoriia dosvidu / M. Holovan // Vyshcha osvita Ukrainy. - 2008. - № 3. - S. 23-30.

10. Panasiuk V. Vykorystannia dosvidu upravlinnia yakosti osvity / V. Panasiuk // Pidruchnyk dlia dyrektora. - 2007. - № 8. - S. 42-51.

11. Kravchenko Yu. Kachestvo obrazovanyia - faktor povyshenyia kachestva zhyzny / Yu. Kravchenko, O. Lebedev // Standarty y kachestvo. - 2007. - № 6. - S. 20-22.

12. Mizherikov V.A. Slovnyk-dovidnyk z pedahohiky / Avt.-uporiad. V.A. Mizherikov; pid zah. red. P.I. Pidkasystoho. - S. 139-140.

13. Moiseiev A. M. Upravlinnia shkoloiu: slovnyk-dovidnyk kerivnyka osvitnoi ustanovy / Pid red. A. M. Moiseieva, A. A. Khlan. - M., 2005. - S. 101-102.

14. Shyshov S. E. Shkola: monytorynh kachestva obrazovanyia / S. E. Shyshov, V. A. Kalnei. - K . : KNEU, 2004. - 167 s.

15. Vorotylov V. Analyz osnovnykh podkhodov k opredelenyiu kachestva obrazovanyia / V. Vorotylov, H. Shaporenkova // Vysshee obrazovanye v Rossyy. - 2006. - № 11. - S. 47-56.

16. Kuchma R. M. Suchasni systemy upravlinnia yakistiu vyshchoi osvity v konteksti vymoh Bolonskoho protsesu / R. M. Kuchma // Visn. Kyiv. nats. un-tu im. Tarasa Shevchenka. Filosofiia. Politolohiia. - 2010. - Vyp. 94-96. - S. 87-93.

17. Pro osvitu : Zakon Ukrainy vid 5 veresnia 2017 roku № 2145-VIII iz zminamy. [Elektronnyi resurs]. - Rezhym dostupu: https://zakon.rada.gov.ua/laws/show/2145-19.

18. Naukovo-osvitnii potentsial natsii: pohliad u KhKhI stolittia: prohramnyi dokument YuNESKO /Avt. kol.: V. Lytvyn, V. Andrushchenko, S. Dovhyi. - K. : Navch. knyha, 2003. - S. 352-354.

19. Opredelenye kachestva v obrazovanyy / Dzhanett Kolbi, Miske Uitt // Materyaly YuNYSEF: doklad 16 yiulia 2000 h. - Niu-York, 2000. - 157 s.

20. Harvey L. Defining quality / L. Harvey, D. Green // Assessment and Evaluation in Higher Education. - 1993. - V. 18 (1). - R. 9-34. $107-111$.

21. Parri J. Quality in Higher Education / J. Parri // Management. - 2006. - № 2 (11) - P.

22. The EFQM Excellence Model. - [Elektronnyi resurs]. - Rezhym dostupu: http://www.ddexcellence.com/About 20 Excellence/Model.git on 6 August 2009.

23. Harantyy kachestva vyssheho obrazovanyia: Hlossaryi // Ekspertyza kachestva professyonalnoho obrazovanyia : materyaly semynara, 20-22 yiunia 2014 h. - M. : MHU ym. M. P. Oharëva, 2014. $-315 \mathrm{~s}$.

24. Natsionalnyi osvitnii hlosarii: vyshcha osvita / [V. M. Zakharchenko, S. A. Kalashnikova, V. I. Luhovyi ta in.] / Za red. V. H. Kremenia. - K. : TOV VD "Pleiady", 2014. $100 \mathrm{~s}$.

25. Pro vyshchu osvitu : Zakon Ukrainy vid 1 lyp. 2014 r. № 1556-VII // Ofits. visn. Ukrainy. - 2014. - № 63. - St. 1728. - [Elektronnyi resurs]. - Rezhym dostupu: http://zakon.rada.gov.ua.

\section{РЕЗЮМЕ}

Владимир Олиферук,

Национальный университет обороны Украины имени Ивана Черняховского 


\section{Качество образования: эволюция представлений в национальном и мировом образовательном пространстве}

В статье рассматривается подходы к определению понятия "качество" с точки зрения философии, экономики, управления. Определены сущзность понятия "качество образования", определен ряд факторов, влияющих на качество образования. Анализируется интегральная характеристика системы образования, отражающая степень соответствия ресурсного обеспечения, образовательного прочесса, образовательных результатов нормативным требованиям, сочиальным и личностным ожиданиям, а оценка качества образования - определение с помощью диагностических и оченочных прочедур степени соответствия ресурсного обеспечения, организации образовательного прочесса, образовательных результатов нормативным требованиям, сочиальным и личностным ожиданиям.

Ключевые слова: высшие учебные заведения; компетентность; процессы обучения; качество образования.

\section{SUMMARY}

Vladimir Oliferuk

National Defence University of Ukraine named after Ivan Cherniakhovskyi

\section{Quality of education: evolution of perceptions in the national and world educational space}

The article considers approaches to the definition of "quality" in terms of philosophy, economics, management. The essence of the concept of "quality of education" is outlined, a number of factors that affect the quality of education are identified. The integral characteristic of the education system is analyzed, which reflects the degree of conformity of resource provision, educational process, educational results to normative requirements, social and personal expectations, and education quality assessment - determination by diagnostic and evaluation procedures of degree of conformity of resource provision requirements, social and personal expectations.

Key words: institutions of higher education; competence; learning processes; quality of education. 